\title{
Effects of inorganic and organic treatments on the microbial community of maize rhizosphere by a shotgun metagenomics approach
}

\author{
Matthew Chekwube Enebe and Olubukola Oluranti Babalola* (1)
}

\begin{abstract}
Purpose: The main drivers of biogeochemical cycling of nutrients, plant growth promotion, and disease suppression are microbes. Organic manure increases soil quality and plant productivity; the same is true of inorganic fertilizer. In this study, we explored shotgun metagenomics study to investigate how maize (Zea mays everta) rhizosphere microbial community diversity is shaped following the application of both compost manure and inorganic fertilizer.

Methods: We used high throughput next-generation sequencing-metagenomics studies to examine the rhizosphere microbial community of maize plants grown in an organic compost manure (8 tons/ha and 4 tons/ha) and inorganic (120 kg/ha NPK and $60 \mathrm{~kg} / \mathrm{ha}$ NPK chemical) fertilized soils. An unfertilized soil was used as a control.

Results: The taxonomic analysis of the soil revealed that regardless of the fertilization regimes, Proteobacteria and Bacteroidetes are distributed across all the samples, but in varying populations. Higher quantities of organic manure (8tons/ha) and lower (60 kg/ha) nitrogen fertilizer, as well as the untreated control, supports the selection and enrichment of Proteobacteria and Actinobacteria, while lower quantities of organic compost ( 4 tons/ha) manure boost the population of Bacteroidetes. Firmicutes, on the other hand, were most abundant in low organic manure (4tons/ha) and higher inorganic (120 kg/ha) fertilized soil. Fungi were selected and enriched by higher ( 8 tons/ha) and lower (4tons/ha) compost manure, while archaea were mostly supported by higher doses of inorganic fertilizers $(120 \mathrm{~kg} / \mathrm{ha})$ and high compost manure ( 8 tons/ha) treatments.

Conclusion: Therefore, comprehending the effects of compost and chemical fertilizers (NPK-20\% nitrogen, $7 \%$ phosphorus, $3 \%$ potassium) on the community structure, dynamics, and abundance of rhizosphere microbiome will help in the manipulation of soil microbial community to increase microbial diversity in the agroecosystem.
\end{abstract}

Keywords: Shotgun metagenomics, Fertilization, Maize rhizosphere, Community diversity, Microbiomes

\section{Introduction}

The global need to increase food crop production has resulted in the constant subjection of the soil to a wide range of disturbances ranging from tillage and plant cultivation to soil fertilization. These practices

\footnotetext{
* Correspondence: Olubukola.Babalola@nwu.ac.za
}

Food Security and Safety Niche Area, Faculty of Natural and Agricultural

Sciences, North-West University, Private Bag X2046, Mmabatho 2735, South Africa

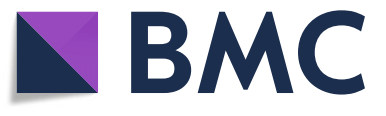

change the ecological balance of the soil by influencing nutrient availability, physical as well as chemical properties of the soil. These perturbations have many effects on the microbiota abundance, viability, and composition. They can make the soil-dwelling microbes to become functionally redundant, metabolically active and, resilient to the changing conditions of the soil environment (Allison and Martiny 2008; Altieri 1999; Babalola et al. 2007).

(c) The Author(s). 2020 Open Access This article is licensed under a Creative Commons Attribution 4.0 International License, which permits use, sharing, adaptation, distribution and reproduction in any medium or format, as long as you give appropriate credit to the original author(s) and the source, provide a link to the Creative Commons licence, and indicate if changes were made. The images or other third party material in this article are included in the article's Creative Commons licence, unless indicated otherwise in a credit line to the material. If material is not included in the article's Creative Commons licence and your intended use is not permitted by statutory regulation or exceeds the permitted use, you will need to obtain permission directly from the copyright holder. To view a copy of this licence, visit http://creativecommons.org/licenses/by/4.0/. 
Conventional intensive soil fertilization systems often depend more on chemical fertilizer application than organic manure. The extensive application of chemical fertilizers hampers crop nutrient uptake, reduces soil quality, and causes environmental hazards like eutrophication, greenhouse gas emissions, etc. (Ding et al. 2014; Hartmann et al. 2015; Zhu et al. 2016). Due to the environmental concerns associated with chemical fertilizer and the need to achieve a sustainable agriculture, current researchers are evaluating the merit of either substituting it with organic manure or combining both organic manure and chemical fertilizers in soil nutrient enrichment for the promotion of a balanced soil microbial ecosystem (Babalola et al. 2009; Bhattacharyya et al. 2008; Tejada et al. 2008).

In the past, regardless of experimental sites and climatic condition, microbial community studies have shown that the diversity of bacteria, as well as other microbes, are increased in soil fertilized with organic manure, as a result of nutrient enrichment of the soil by the manure (Chávez-Romero et al. 2016; Hamm et al. 2016). Chaudhry et al. (2012) demonstrated in a study involving a comparison of soil fertilization with organic manure (compost) and chemical fertilizer that the former enhanced certain bacterial phyla populations better than the latter, as a result of improved soil carbon and nitrogen.

The biodiversity of soil microbes is increased by soil fertilization; nevertheless, plants regulate rhizosphere microbial communities through root exudation in the form of rhizodeposition, temperature, and moisture control, etc. (Denef et al. 2009). Zea mays everta (Maize), an important food crop and animal feed, is a crop grown in Africa and in particular North West Province of South Africa, amongst other nations, and has an influence on the selection, enrichment, and sustenance of rhizosphere microbial community (Ranum et al. 2014). Microbes perform crucial roles in the biogeochemical cycling processes in the soil as well as in disease suppression.

Shotgun metagenomics approach, in the past, has been used to evaluate and comprehend microbial taxonomic diversity and functions in the soil, sediments, composts, and water samples (Andreote et al. 2012; Babalola 2010; Martins et al. 2013; Mendes et al. 2014; Meneghine et al. 2017). In this study, we aimed to use a shotgun metagenomics study to investigate the influence of inorganic and organic fertilizers on the taxonomic abundance, diversity, and structure of maize rhizosphere microbial community and to ascertain whether there is any difference between maize plants and fertilizers in the selection and enrichment of microbial community in the soil.

\section{Materials and methods Soil sampling}

The 5 soil samples used were sourced from NorthWest University's Molelwane farm planted with maize $\left(25^{\circ} 47^{\prime} 24.17604^{\prime \prime} \mathrm{S}, 2^{\circ} 37^{\prime} 9.08328^{\prime \prime} \mathrm{E} ; 25^{\circ}\right.$ $47^{\prime} 29.97048^{\prime \prime}$ S, $25^{\circ} 37^{\prime} 8.62428^{\prime \prime}$ E; $25^{\circ} 47^{\prime} 23.9604^{\prime \prime}$ S, $25^{\circ} 37^{\prime} 8.43348^{\prime \prime}$ E; $25^{\circ} 47^{\prime} 23.82252^{\prime} \mathrm{S}, 25^{\circ} 37^{\prime}$ 8.30064" E; $25^{\circ} 47^{\prime} 24.11844^{\prime \prime}$ S, $25^{\circ} 37^{\prime} 8.18148^{\prime \prime}$ E; altitude $1012 \mathrm{~m})$. Sampling was done in October 2018 at 7 weeks after the germination of the maize seed. The experimental plots were treated with 120 $\mathrm{kg}$ and $60 \mathrm{~kg}$ of NPK fertilizer (N/ha) and with community-based compost manure at 8 tons and 4 tons/ha respectively. The maize (Zea mays everta) planting distance was $15 \mathrm{~cm} \times 20 \mathrm{~cm}$. The rhizosphere of soil samples was collected using auger at 0-15 cm depth. The sampling area was split into 3 plots for $60 \mathrm{~kg} \mathrm{~N} / \mathrm{ha}$ and 3 plots for $120 \mathrm{~kg} \mathrm{~N} / \mathrm{ha}$. The control and the compost treatments were split into 3 plots each. Soil samples were taken from 9 plants (3 from each replicate/treatments). Therefore, a total of 15 samples were collected ( 3 replicates $\times 5$ treatments). From each sub-replicated plot of the treatments, nine sub-samples distributed to cover the entire plots were gathered together into composite samples. Each of the five treatments was made up of five composite samples, each containing nine subsamples. The soil samples were put in a plastic bag covered with ice and conveyed to the laboratory, plant and root debris were sieved (with 2-mm sieve) and preserved at $-20{ }^{\circ} \mathrm{C}$. The physicochemical properties of the soil before planting and fertilization were analyzed through following the standard basic soil chemical analysis protocols described by Motsara and Roy (2008) and the results are contained in Table 1.

\section{Metagenomics DNA isolation and shotgun sequencing}

A PowerSoil community DNA isolation kit from Mo Bio Laboratories, Inc. Carlsbad was used to isolate microbial community DNA from $0.25 \mathrm{~g}$ of the soil samples following the manufacturer's instruction. The Nextera DNA Flex library preparation kit (Illumina Incorporation) was used to prepare the libraries following the protocols in the manufacturer's manual. The initial DNA concentrations were determined using the Qubit $^{\circ}$ dsDNA HS Assay Kit of Life Technologies. A total of $50 \mathrm{ng}$ extracted DNA was used for the libraries' preparation. The samples passed through simultaneous fragmentation and adapter sequences were added. During the 6 cycles of PCR, the 
Table 1 Physicochemical properties of the soil prior to planting and fertilization

\begin{tabular}{ll}
\hline Soil property & Value \\
\hline Physical characteristics & \\
\% Sand & 80 \\
\% Silt & 5 \\
\% Clay & 15 \\
Chemical properties & \\
pH (1:2.5 water) & 4.97 \\
Total nitrogen (\%) & 0.038 \\
Total bray 1 phosphorus (\%) & 0.001 \\
Total potassium (\%) & 0.0285 \\
Total calcium (\%) & 0.0388 \\
Total magnesium (\%) & 0.0162 \\
Total sodium (\%) & 0.0005 \\
\% carbon & 0.36 \\
S-Value (sum of extractable Ca, Mg, K, and $\mathrm{Na})(\mathrm{cmol}(+) / \mathrm{kg})$ & 4.59 \\
\% Calcium & 48.0 \\
\% Magnessium & 33.2 \\
\% Potassium & 18.3 \\
\% Sodium & 0.5 \\
Extractable acidity (me \%) & 0.03 \\
\hline
\end{tabular}

adapters, and the unique indices were introduced into the samples. After the preparation of the libraries, the concentration was measured using the Qubit $^{\circ}$ dsDNA HS Assay Kit from Life Technologies. Also, the library sizes (average) were determined using the Agilent 2100 Bioanalyzer from Agilent Technologies. An equal-molar ratio of the libraries $(0.7 \mathrm{nM})$ was pooled together and sequenced paired-end for 300 cycles with NovaSeq 6000 system machine (Illumina). This sequencing was carried out by Mr DNA of the Molecular Research Laboratory (USA).

\section{Metagenomics sequence annotation and statistical analysis}

The shotgun raw sequences generated from the microbial community DNA were uploaded to the MG-RAST online server (Meyer et al. 2008). This online annotation system pipeline performed many quality controls following their standard protocol in the removal of artificial sequences arising from the sequencing process (dereplication), removal of host-specific species-sequences, ambiguous base, and read length filtering. The sequences were annotated through blasting using BLAT (BLAST-like alignment tool algorithm) against M5NR databases (Kent 2002). The taxonomic profile was done by Best Hit at E-value cutoff of $1 \times 10^{-5}$, minimum alignment length of 15 base pairs, minimum percentage identity cutoff of 60 based on the RefSeq annotation database sources (Wilke et al. 2012) using MG-RAST. The distribution of the domains, phyla, class, and genus of the taxonomic profile were analyzed only for bacteria because of its dominance in the samples. For fungi and archaea, only phylum levels were considered.

\section{Statistical analysis}

Canoco software $5 \mathrm{v}$ was employed in plotting and data representation for PcoA (principal coordinate Analysis) and principal component analysis (PCA). While the taxonomic abundance heatmap at z-score of -1 to 1 using relative abundance data was generated using heatmapper online tool (www1.heatmapper.ca/expression/). Evenness, Simpson, and Shannon diversity index were evaluated for the samples, and their diversity indices were compared across the treatments using a Kruskal-Wallis test, and they were calculated on PAST statistical software (Hammer et al. 2001). Beta diversity was shown by the PCoA (principal coordinate analysis) based on Euclidean distance-matrix and ANOSIM (one-way analysis of similarities) (Clarke and Green 1988). The principal component analysis (PCA) was used to depict the distribution of taxonomic categories between the maize rhizosphere samples. The sequences were deposited in NCBI SRA database, SRA accession: PRJNA607213

\section{Results}

Fertilizer treatments effects on microbial community structure in the maize rhizosphere

In order to evaluate the microbial community structure of maize (Zea mays everta) plants' rhizosphere at different fertilizers treatments, the generated sequence reads were used in calculating Bray Curtis similarity matrices and used to carry out PCoA (principal coordinate analysis). Microbial communities could be separated based on the treatments with four major clusters (Fig. 1). The axis 1 corresponds to $96.12 \%$ variation, separating the samples according to the use of organic manure (compost) and inorganic fertilizers. On the left-hand side, the samples show those treatments receiving moderate inorganic (60 kg/ha NPK-N60) fertilizer and high levels of compost manure (8 tons/ha). The low inorganic fertilizer treatments tend to cluster together with the untreated control. The samples at the right side are those ones that are receiving moderate and high input of compost manure and inorganic fertilizer.

Principal component analysis (PCA) was also generated for the treatments to obtain a treatments effects on the bacterial community structure in particular. There is 


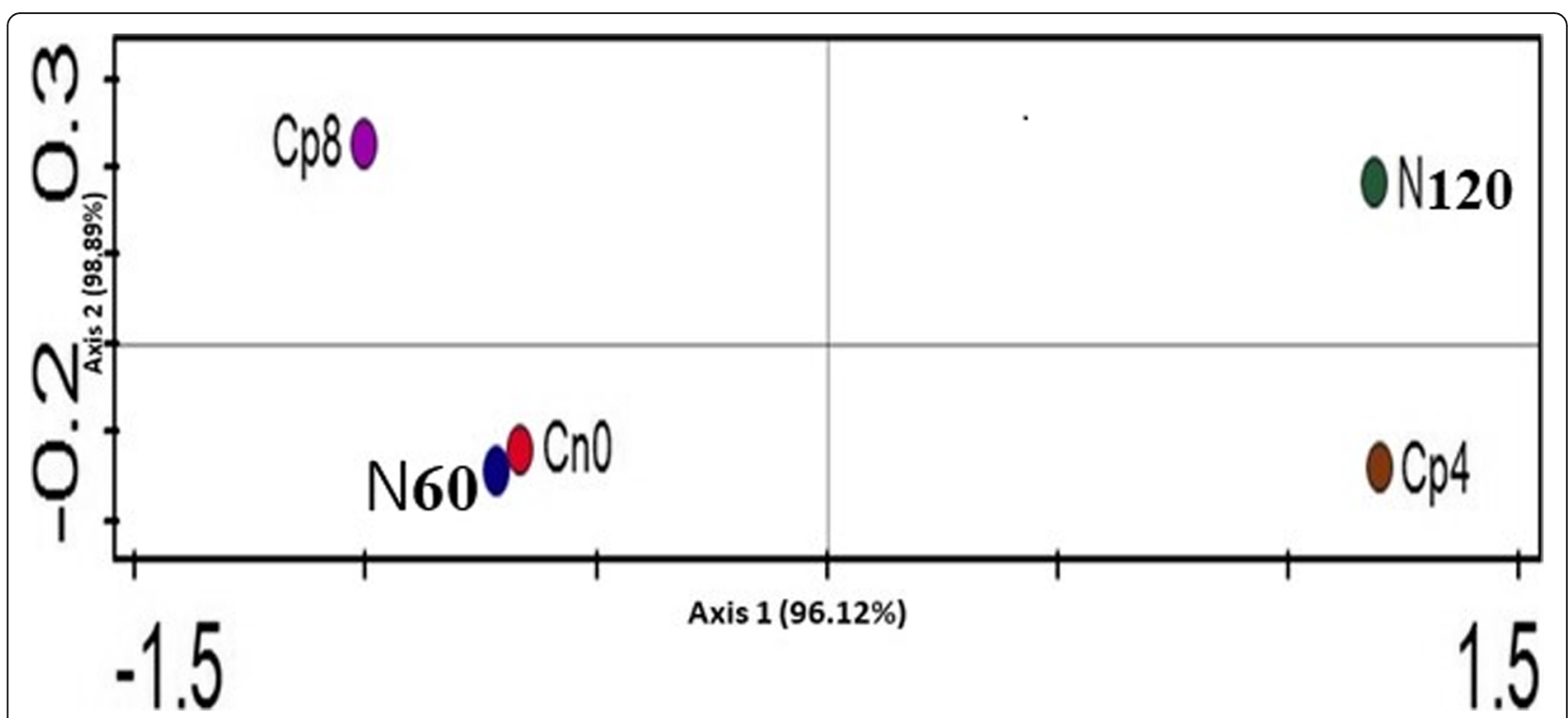

Fig. 1 PCoA (Principal Coordinate Analysis) showing the beta diversity between the maize rhizosphere soils at different fertilization regimes, Cn0 (control), N60 (60 kg/ha NPK), N120 (120 kg/ha NPK), Cp8 (8 tons/ha compost), and Cp4 (4 tons/ha compost manure)

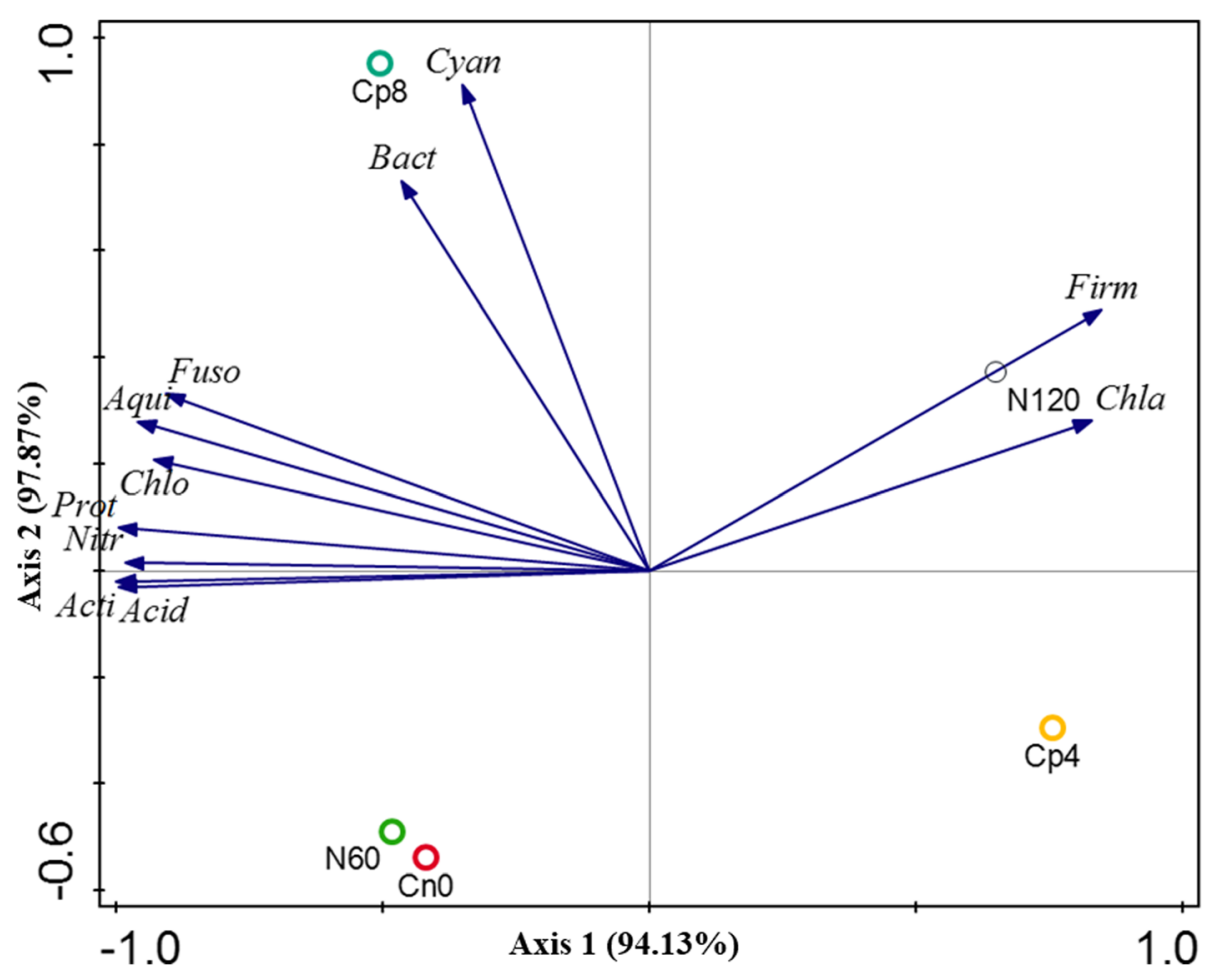

Fig. 2 PCA (principal component analysis) of the bacterial community structure associated with maize rhizosphere grown under different fertilization and unfertilized regimes (compost 8 tons/ha—Cp8, compost 4 tons/ha—Cp4, control—CnO, 60 kg/ha inorganic fertilizer-N60, 120 kg/ha inorganic fertilizer-N120), showing treatments as the key factors influencing the structural shift and shape of bacterial community at the rhizosphere soil samples. The percentages represent the observed variations 
an appreciable fertilizer effect on the bacterial community structure at the phylum level (Fig. 2). The highest dose of compost manure (8 tons/ha)-treated soil, low inorganic $(60 \mathrm{~kg} / \mathrm{ha})$ fertilizer and the control exerted maximum selection effects in the bacterial community compared to the high inorganic fertilizers and the medium dose of compost manure treatment. However, the fertilization of the soil with a community-based compost manure resulted in both discrimination and community shifts in the rhizosphere samples of maize plants.

\section{Comparison of the different rhizosphere soil samples metagenomes}

The taxonomic community of the maize rhizosphere soil metagenomes analysis revealed that the samples were dominated by bacteria (98.2\%), with Eukaryota being approximately $1.2 \%$, viruses $2.2 \%$, and archaea $(0.8 \%)$ of the assigned total reads in any of the samples (Fig. 3) There was a marked difference in the microbes' composition at the domain-level in the taxa amidst the various fertilizer treatments. The highest was shown in the bacteria domain. Here, the majority of the sequences were mapped to the $\mathrm{Cp} 8$ ( 8 tons/ha compost), N1 (60 kg/ha inorganic fertilizer), N2 $(120 \mathrm{~kg} / \mathrm{ha}$ inorganic fertilizer), and $\mathrm{Cn} 0$ (unfertilized control), while the Cp4 (4tons/ha compost) had considerably lower numbers of sequences $(P<0.05)$. Viruses and Eukaryota occur most in low compost (4 tons/ha) manure-treated rhizosphere soil, while archaea dominated in $120 \mathrm{~kg} / \mathrm{ha}$ (N2) inorganic fertilizertreated soil (Fig. 3).
However, viruses were very low in the control and N1 $(60 \mathrm{~kg} / \mathrm{ha})$ treatments, but very abundant with the introduction of 4 tons compost and a higher quantity of inorganic fertilizer (N2-120 kg/ha NPK) $(P<0.05)$. The viral families observed revealed that Circoviridae, Inoviridae, and Microviridae were most abundant in lower organic manure-treated rhizospheric soil (Cp4), while Myoviridae, Podoviridae, and Siphoviridae were abundant in $\mathrm{Cp} 8$ (higher dose of organic manure-treated soil) (Fig. 4). Eukaryota was higher in $\mathrm{Cp} 8$ and $\mathrm{Cp} 4$ treatments with Glomeromycota, Ascomycota, Basidiomycota highly abundant in Cp8 treatments. Blastocladiomycota and Chrytridiomycota were most abundant in $\mathrm{Cp} 4$ treatments. Statistical differences were observed regarding the control, N1, and N2 $(P<0.05)$ treatments (Fig. 5). Archaea, on the other hand, were most abundant in Cp8 and N2 treatments. Cp8 treatment contains a higher abundance of Korarchaeota and Euryarchaeota, while Nanoarchaeota, Crenarchaeota, and Thaumarchaeota were most abundant in N2-treated samples (Fig. 5).

Regardless of the fertilization treatment applied, the bacterial reads mapped to Proteobacteria and Actinobacteria were present across all samples, with the highest abundance present in $\mathrm{Cp} 8, \mathrm{~N} 1$, and $\mathrm{Cn} 0$ (Fig. 6). Bacteroidetes exhibited nearly the same abundance level in all the treatments but were highest in Cp8 sample. Firmicutes, on the other hand, were most predominant in $\mathrm{Cp} 4$ and $\mathrm{N} 2$ respectively (Fig. 5). Within the phylum and class level, Proteobacteria and Alphaproteobacteria are dominant in

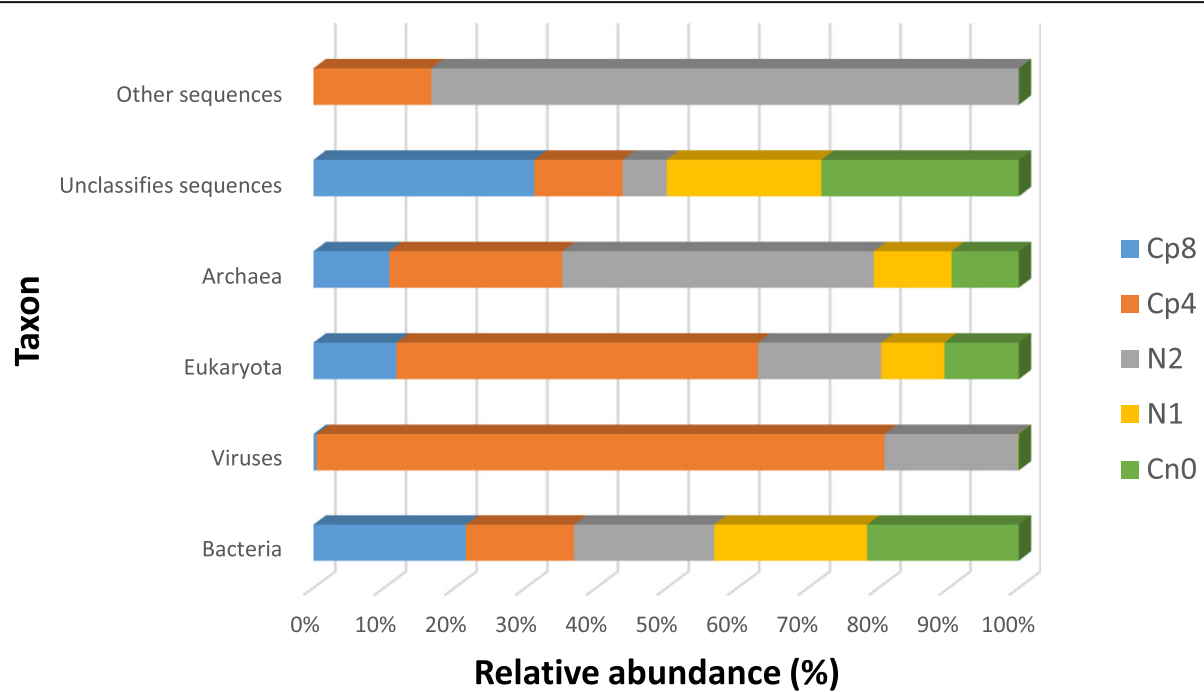

Fig. 3 The microbial taxa's relative abundance at the domain level within maize rhizosphere soil samples. The treatment is compost 8 tons/ha (Cp8), compost 4 tons/ha (Cp4), inorganic N-120 kg N/ha (N2), inorganic N—60 kg/ha (N1), and control (Cn0) 


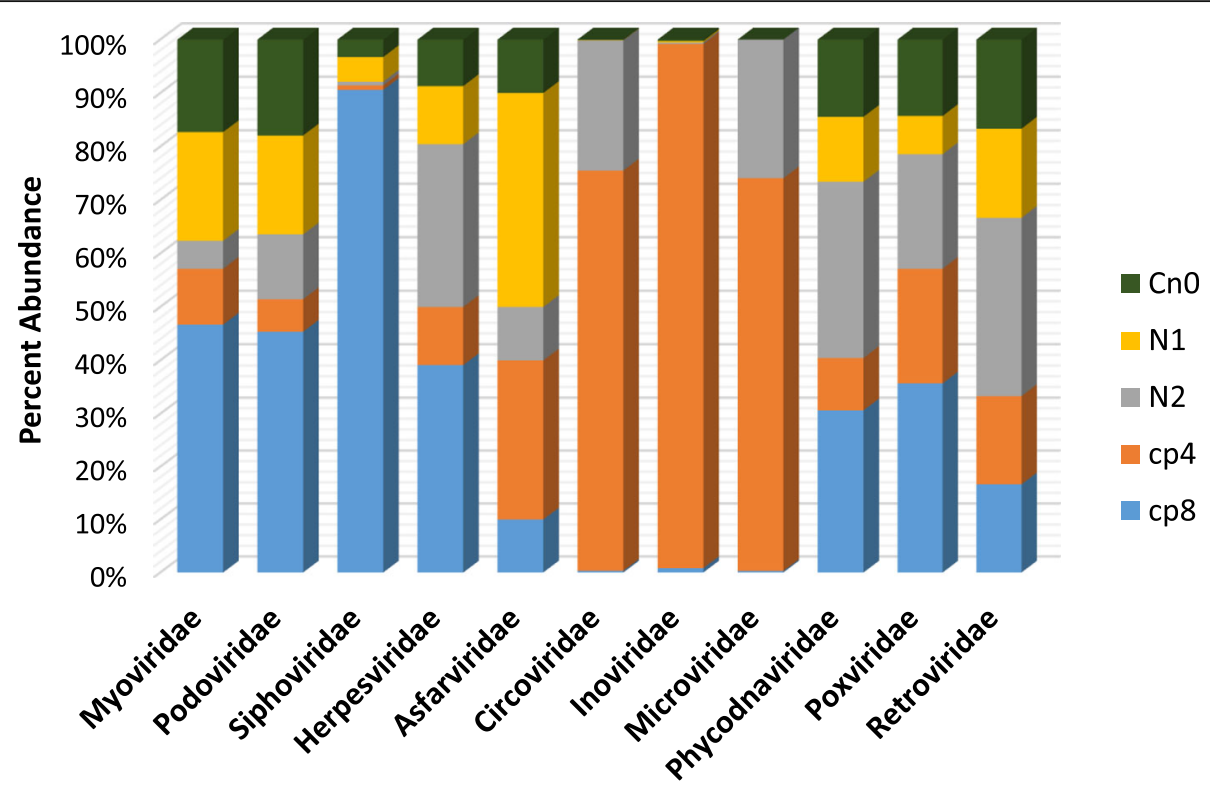

Fig. 4 Percent abundance of major viral families present in the maize rhizosphere under the fertilization treatments, CnO (control), N1 (60 kg/ha NPK), N2 (120 kg/ha NPK), Cp8 (8 tons/ha compost), and Cp4 (4 tons/ha compost manure)

Cp8, N1, and Cn0 samples. While Gammaproteobacteria predominates in $\mathrm{Cp} 4$ and $\mathrm{N} 2$ samples (Figure S1). Actinobacteria were the second most abundant bacteria in the phylum-domain and were not generally different amidst the fertilizer treatments: $\mathrm{Cp} 8$, $\mathrm{N} 1$, and $\mathrm{Cn} 0(P<0.05)$, except for $\mathrm{Cp} 4$ and $\mathrm{N} 2$ treatments. At the class level, Bacilli were most abundant in $\mathrm{Cp} 4$ and $\mathrm{N} 2$, while in the other treatments, they were very minute in abundance. Chloroflexi were also abundant in the control, $\mathrm{Cp} 8$ and $\mathrm{N} 1$ samples, while Verrucomicrobia predominates in the control and Cp8. Chlorobia, however, dominated in

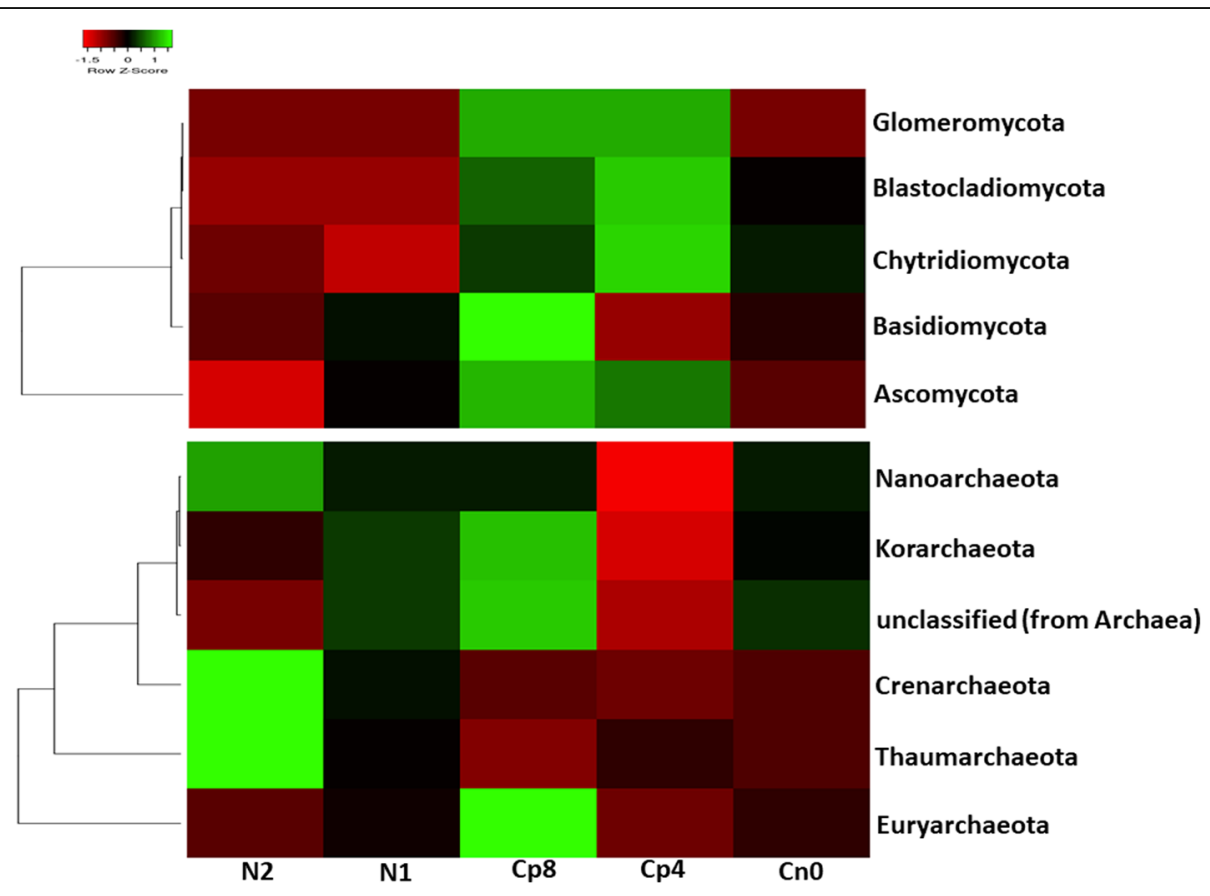

Fig. 5 Heatmap representation of the abundance of fungal and Archaeal community within the treatments from maize rhizosphere samples, Cn0 (control), N1 (60 kg/ha NPK), N2 (120 kg/ha NPK), Cp8 (8 tons/ha compost), and Cp4 (4 tons/ha compost manure) 


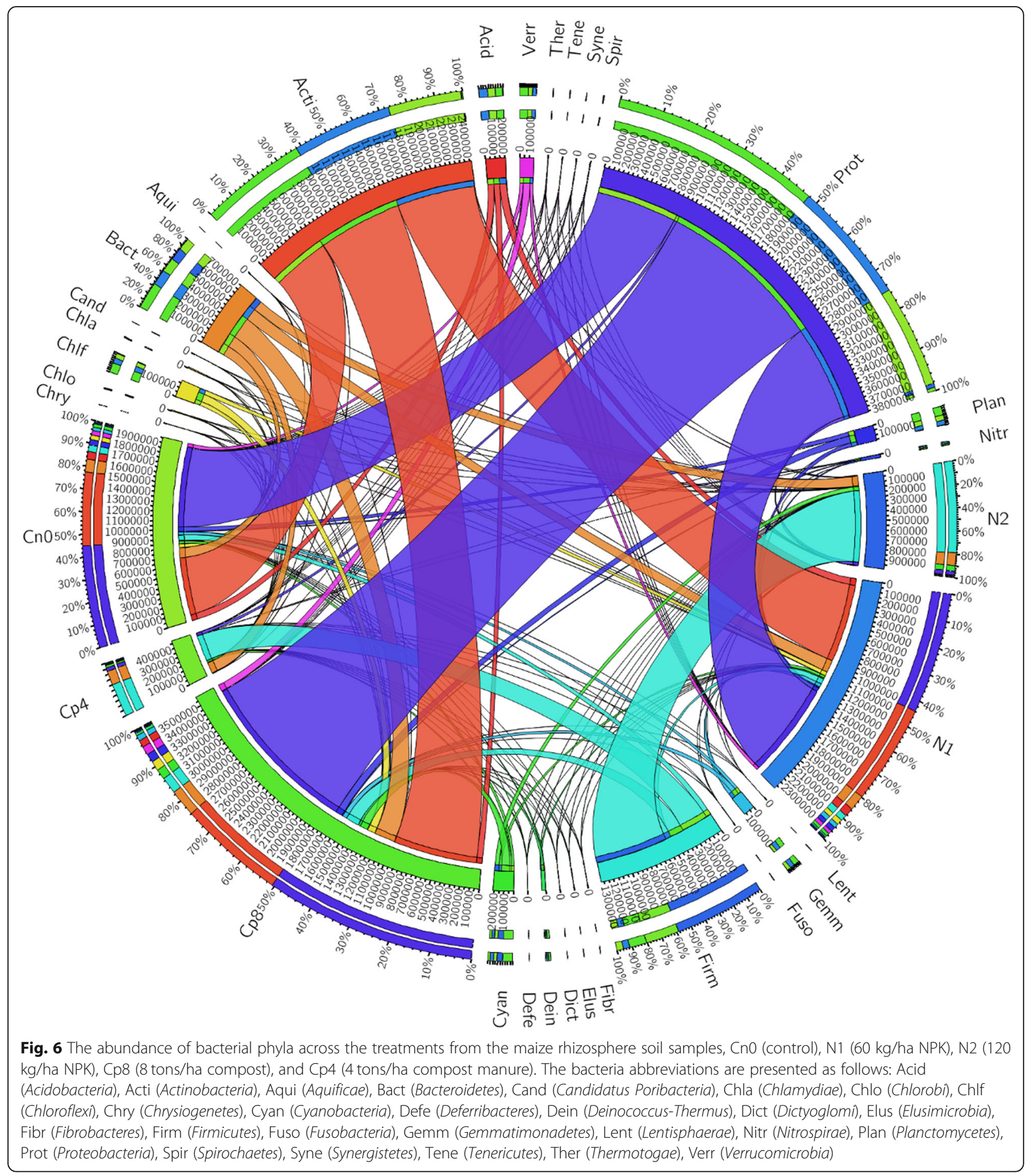

the compost treated soil ( $\mathrm{Cp} 8$ and $\mathrm{Cp} 4)$ as well as in control (Fig. 6). The most abundant genus was $\mathrm{Ba}$ cillus (with a relative abundance of $49.78 \%$ and $79 \%$ ) belonging to the phylum-Firmicutes are present in both $\mathrm{Cp} 4$ and N2 samples. In comparison, the abundances between rhizosphere samples revealed that the genera Streptomyces and Conexibacter were in higher abundance in $\mathrm{Cp} 8, \mathrm{~N} 1$, and control samples compared with Cp4 and N2 (Figure S1), while the Chitinophaga are in greater abundance in $\mathrm{Cp} 4$ and N2. The next statistically significant genus present in this study is Nocardiodes, abundant in soil treated 
with a lower quantity of inorganic fertilizer (N1). Moreover, Candidatus Solibacter were also present in $\mathrm{N} 1$ and control samples. Also observed were Saccharomonospora and Sorangium in $\mathrm{Cp} 8$ treatment only compared to others (Table S1).

\section{Diversity (alpha and beta) of the bacteria in the treated rhizosphere soil samples}

The Simpson, Evenness, and Shannon diversity indices showed an insignificant difference $(P>0.05)$ between $\mathrm{N} 1, \mathrm{Cp} 8$, and Cn0, but differed with N2- and Cp4treated rhizosphere soil samples (Fig. 7). The KruskaWallis test revealed a significant difference $(P=0.001)$ in the diversity of bacteria within the rhizosphere soil samples. However, the analysis of similarity (ANOSIM) was significant for the samples (with $P$ value of 0.01 and $R$ value of 0.55 ).

\section{Discussion}

Soil fertilization is an age-long agricultural practice aimed at increasing soil fertility for maximum crop performance and yield. Recently, researchers have focused on unraveling the impact of the fertilization regimes on the microbial communities in the soil. In this experimental study, we examined the response of maize bacterial, fungi, and archaeal communities to compost and inorganic fertilization regimes. The results showed that fertilizer treatments influenced the maize rhizosphere microbial community. The influence of fertilization regimes on the bulk soil microbes has been known (Chen et al. 2016; Francioli et al. 2016). Until recently, however, very little was known of the effects of fertilizers on maize microbes' rhizosphere community. The analysis of the fertilizertreated soils showed a marked shift in the microbes' community structure at the rhizosphere, but it is still unclear whether this temporal selection is caused by the maize plants selective pressure or the microbes themselves.

The 8 tons/ha compost-treated rhizosphere soil and the control samples were similar, indicating that organic manure provided the most stable community, and this is in agreement with Tkacz et al. (2015) as well as the maize plant selection effect, which could be attributed to chemical signaling compounds produced by the plants' roots (Neal et al. 2012). The relationship between the microbial community enrichment effects of organic manure and maize plants are both capable of increasing the soil organic carbon. Maize performs this by rhizodeposition (Philippot et al. 2013) and organic manure by soil nutrient enrichment ( $\mathrm{Ai}$ et al. 2015). It is also proposed that a small quantity of microbes are likely to be introduced into the soil by the maize seeds (endophytes). A recent study has demonstrated that the number of bacteria, as well as their diversity, are

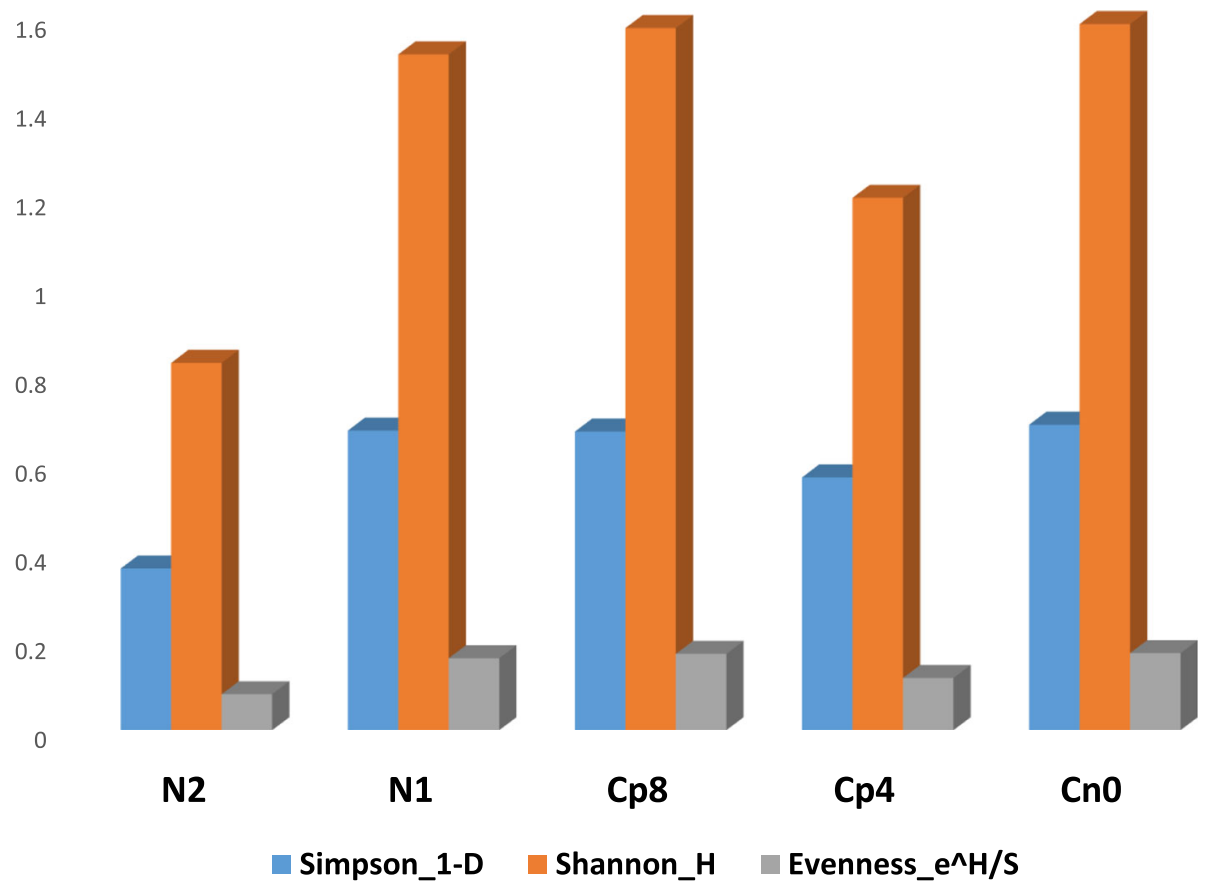

Fig. 7 Diversity indices for bacterial phylum within the maize rhizosphere treated with organic and inorganic fertilizer as well as under control condition. Cn0 (control), N1 (60 kg/ha NPK), N2 (120 kg/ha NPK), Cp8 (8 tons/ha compost), and Cp4 (4 tons/ha compost manure) 
higher at the rhizosphere than in the inner tissues of maize plants (Pereira et al. 2011). Amendment of rhizosphere soil with compost manure showed the highest richness and diversity of bacteria, fungi, and archaea, followed by a low quantity of inorganic fertilizer and the control samples. To what extent, the compost supplied the soil with microbes is still unclear. Therefore, caution should be applied in comparing inorganic fertilized soil with compost-amended soils. Our study suggests that there exists an inversely proportional relationship between inorganic fertilizers and the diversity and abundance of the microbial community. The least observable abundance and diversity were found in samples treated with higher inorganic fertilizer and low compost manure-treated soil and are in concurrence with other studies (Campbell et al. 2010; Zeng et al. 2016).

Microbial communities (bacteria, fungi, and archaea) in the rhizosphere soil treated with compost manure, however, were more distinct from higher inorganic fertilizer-treated soil, and this agrees with studies done by Sun et al. (2004) and Ai et al. (2015). Surprisingly, soil treated with a medium quantity of inorganic fertilizer possesses nearly the same effect in the promotion of similar microbial population and structure as the higher dose compost and the control soil. This implies that moderate soil fertilization will have a low or mild alteration of soil chemical properties $(\mathrm{pH})$ (Zhang et al. 2017) while supplying the required nutrients for the plants and promoting microbial growth and metabolism. In this way, maize plants could be able to exert proper rhizosphere effects on the surrounding soil-dwelling microbes. In this study, there is a shift in trend as well as anomaly observed. The low dose of compost amendment has the same effect on the rhizosphere microbial communities as do the higher inorganic fertilizers. The mechanism behind the former is still unclear, but the latter could be attributed to negative interference on plant-microbes interaction (Grillo et al. 2016; Wei et al. 2013), soil acidification (Griffiths et al. 2011), reduced microbial respiration, and loss of biodiversity (Ramirez et al. 2012; Wallenstein et al. 2006; Xu et al. 2012). At the genus level for bacteria, these two treatments supported the abundance of Bacillus and Chitinophaga at the rhizosphere of maize. These organisms are spore formers and highly resistant to environmental stress (Kuramae et al. 2012; Sangkhobol and Skerman 1981).

\section{Conclusion}

This study brings to light the effects of soil fertilization with community-based compost and inorganic NPK (20: $7: 3$ ) fertilizer on the maize microbial communities and, in agreement with previous studies, revealed that higher levels of inorganic fertilizer treatments affect drastically the microbial community structure and abundance in the agricultural soil. Lower doses of nitrogen fertilizer and higher compost manure application boost the richness, abundance, and diversity of the bacteria, fungi, and archaea, thereby enhancing the attainment of a stable community at the rhizosphere. Surprisingly, the effects of a higher dose of inorganic fertilizer were the same as the lower dose of the compost-treated soil, except for the enrichment of the archaeal community by the higher inorganic fertilizer treatment and fungal community by the lower compost manure. While the former could be understood, the latter remains unclear and requires further studies. The control shows that maize plants have very significant effects on the selection and enrichment of soil microbes' community. Therefore, to achieve maximum results in promoting plant health, productivity, and the microbial community, an integrated fertilizer approach of using 8 tons/ha compost and $60 \mathrm{~kg} / \mathrm{ha}$ inorganic fertilizer is recommended.

\section{Supplementary information}

Supplementary information accompanies this paper at https://doi.org/10 1186/s13213-020-01591-8

Additional file 1: Table S1. Diversity indices of the bacterial genus from the rhizosphere soil samples of maize under different fertilization regime. Figure S1. Taxonomic categories at the class, phylum and genus across all the treatments.

\section{Acknowledgements}

M.C.E. is supported by the NRF-TWAS/African Renaissance Doctoral Scholarship. This work is based on the research supported by the National Research Foundation of South Africa (Grants Ref: UID123634; OOB).

\section{Authors' contributions}

MCE and $O O B$ conceived and designed the experiment, conducted it, wrote the manuscript and analyzed the data. All author(s) read and approved the final manuscript.

\section{Funding}

The study was funded by the National Research Foundation of South Africa (Grants Ref: UID123634; OOB).

Ethics approval and consent to participate

This article does not contain any studies with human participants or animals performed by any of the authors.

\section{Consent for publication}

Informed consent was obtained from the individual participants involved in this study.

\section{Competing interests}

The authors declare that they have no conflict of interest.

Received: 24 April 2020 Accepted: 8 July 2020

Published online: 31 July 2020

\section{References}

Ai C, Liang G, Sun J, Wang X, He P, Zhou W, He X (2015) Reduced dependence of rhizosphere microbiome on plant-derived carbon in 32-year long-term inorganic and organic fertilized soils. Soil Biol Biochem 80:70-78

Allison SD, Martiny JB (2008) Resistance, resilience, and redundancy in microbial communities. Proc Nat Acad Sci 105:11512-11519 
Altieri MA (1999) The ecological role of biodiversity in agroecosystems Invertebrate biodiversity as bioindicators of sustainable landscapes. Elsevier, pp 19-31

Andreote FD, Jiménez DJ, Chaves D, Dias ACF, Luvizotto DM, Dini-Andreote F, Fasanella CC, Lopez MV, Baena S, Taketani RG (2012) The microbiome of Brazilian mangrove sediments as revealed by metagenomics. PLoS One 7(6)

Babalola $\mathrm{OO} \mathrm{(2010)} \mathrm{Beneficial} \mathrm{bacteria} \mathrm{of} \mathrm{agricultural} \mathrm{importance.} \mathrm{Biotechnol} \mathrm{Lett}$ 32(11):1559-1570

Babalola OO, Kirby BM, Le Roes-Hill M, Cook AE, Cary SC, Burton SG, Cowan DA (2009) Phylogenetic analysis of actinobacterial populations associated with Antarctic Dry Valley mineral soils. Environ Microbiol 11(3):566-576

Babalola OO, Sanni Al, Odhiambo GD, Torto BJ (2007) Plant growthpromoting rhizobacteria do not pose any deleterious effect on cowpea and detectable amounts of ethylene are produced. World J Microbiol Biotechnol 23(6):747-752

Bhattacharyya R, Kundu S, Prakash V, Gupta H (2008) Sustainability under combined application of mineral and organic fertilizers in a rainfed soybeanwheat system of the Indian Himalayas. Eur J Agron 28(1):33-46

Campbell BJ, Polson SW, Hanson TE, Mack MC, Schuur EA (2010) The effect of nutrient deposition on bacterial communities in Arctic tundra soil. Environ Microbiol 12(7):1842-1854

Chaudhry V, Rehman A, Mishra A, Chauhan PS, Nautiyal CS (2012) Changes in bacterial community structure of agricultural land due to long-term organic and chemical amendments. Microb Ecol 64(2):450-460

Chávez-Romero Y, Navarro-Noya YE, Reynoso-Martínez SC, Sarria-Guzmán Y, Govaerts B, Verhulst N, Dendooven L, Luna-Guido M (2016) $16 \mathrm{~S}$ metagenomics reveals changes in the soil bacterial community driven by soil organic $\mathrm{C}$, N-fertilizer and tillage-crop residue management. Soil Tillage Res 159:1-8

Chen L, Liu Y, Wu G, Veronican Njeri K, Shen Q, Zhang N, Zhang R (2016) Induced maize salt tolerance by rhizosphere inoculation of Bacillus amyloliquefaciens SQR9. Physiol Plant 158(1):34-44

Clarke K, Green R (1988) Statistical design and analysis for a'biological effects' study. Mar Ecol Prog Ser:213-226

Denef K, Roobroeck D, Wadu MCM, Lootens P, Boeckx P (2009) Microbial community composition and rhizodeposit-carbon assimilation in differently managed temperate grassland soils. Soil Biol Biochem 41(1):144-153

Ding L-J, An X-L, Li S, Zhang G-L, Zhu Y-G (2014) Nitrogen loss through anaerobic ammonium oxidation coupled to iron reduction from paddy soils in a chronosequence. Environ Sci Technol 48(18):10641-10647

Francioli D, Schulz E, Lentendu G, Wubet T, Buscot F, Reitz T (2016) Mineral vs. organic amendments: microbial community structure, activity and abundance of agriculturally relevant microbes are driven by long-term fertilization strategies. Front Microbiol 7:1446

Griffiths RI, Thomson BC, James P, Bell T, Bailey M, Whiteley AS (2011) The bacterial biogeography of British soils. Environ Microbiol 13(6):1642-1654

Grillo MA, Stinchcombe JR, Heath KD (2016) Nitrogen addition does not influence pre-infection partner choice in the legume-rhizobium symbiosis. Amer J Bot 103(10):1763-1770

Hamm AC, Tenuta M, Krause DO, Ominski KH, Tkachuk VL, Flaten DN (2016) Bacterial communities of an agricultural soil amended with solid pig and dairy manures, and urea fertilizer. Appl Soil Ecol 103:61-71

Hammer $\varnothing$, Harper DA, Ryan PD (2001) PAST: Paleontological statistics software package for education and data analysis. Palaeontol Electron 4(1):9

Hartmann M, Frey B, Mayer J, Mäder P, Widmer F (2015) Distinct soil microbial diversity under long-term organic and conventional farming. ISME J 9(5): 1177-1194

Kent WJ (2002) BLAT-the BLAST-like alignment tool. Genome Res 12(4):656-664 Kuramae EE, Yergeau E, Wong LC, Pijl AS, van Veen JA, Kowalchuk GA (2012) Soil characteristics more strongly influence soil bacterial communities than landuse type. FEMS Microbiol Ecol 79(1):12-24

Martins LF, Antunes LP, Pascon RC, de Oliveira JCF, Digiampietri LA, Barbosa D, Peixoto BM, Vallim MA, Viana-Niero C, Ostroski EH (2013) Metagenomic analysis of a tropical composting operation at the São Paulo Zoo Park reveals diversity of biomass degradation functions and organisms. PLoS One 8(4)

Mendes LW, Kuramae EE, Navarrete AA, Van Veen JA, Tsai SM (2014) Taxonomical and functional microbial community selection in soybean rhizosphere. ISME J 8(8):1577-1587

Meneghine AK, Nielsen S, Varani AM, Thomas T, Alves LMC (2017) Metagenomic analysis of soil and freshwater from zoo agricultural area with organic fertilization. PLoS One 12(12)
Meyer F, Paarmann D, D'Souza M, Olson R, Glass EM, Kubal M, Paczian T, Rodriguez A, Stevens R, Wilke A (2008) The metagenomics RAST server-a public resource for the automatic phylogenetic and functional analysis of metagenomes. BMC Bioinfo 9(1):386

Motsara MR, Roy RN (2008) Guide to laboratory establishment for plant nutrient analysis, vol 19. Food and Agriculture Organization of the United Nations, Rome

Neal AL, Ahmad S, Gordon-Weeks R, Ton J (2012) Benzoxazinoids in root exudates of maize attract Pseudomonas putida to the rhizosphere. PLoS One 7(4)

Pereira P, Ibáñez F, Rosenblueth M, Etcheverry M, Martínez-Romero E (2011) Analysis of the bacterial diversity associated with the roots of maize (Zea mays L.) through culture-dependent and culture-independent methods. ISRN Ecol

Philippot L, Raaijmakers JM, Lemanceau P, Van Der Putten WH (2013) Going back to the roots: the microbial ecology of the rhizosphere. Nat Rev Microbiol 11(11):789-799

Ramirez KS, Craine JM, Fierer N (2012) Consistent effects of nitrogen amendments on soil microbial communities and processes across biomes. Glob Chang Biol 18(6):1918-1927

Ranum P, Peña-Rosas JP, Garcia-Casal MN (2014) Global maize production, utilization, and consumption. Ann N Y Acad Sci 1312(1):105-112

Sangkhobol V, Skerman V (1981) Chitinophaga, a new genus of chitinolytic myxobacteria. Int J Syst Evol Microbiol 31(3):285-293

Sun H, Deng SP, Raun WR (2004) Bacterial community structure and diversity in a century-old manure-treated agroecosystem. Appl Environ Microbiol 70(10): 5868-5874

Tejada M, Gonzalez J, García-Martínez A, Parrado J (2008) Effects of different green manures on soil biological properties and maize yield. Bioresour Technol 99(6):1758-1767

Tkacz A, Cheema J, Chandra G, Grant A, Poole PS (2015) Stability and succession of the rhizosphere microbiota depends upon plant type and soil composition. ISME J 19(11):2349-2359

Wallenstein MD, McNulty S, Fernandez IJ, Boggs J, Schlesinger WH (2006) Nitrogen fertilization decreases forest soil fungal and bacterial biomass in three long-term experiments. Forest Ecol Manag 222(1-3):459-468

Wei C, Yu Q, Bai E, Lü X, Li Q, Xia J, Kardol P, Liang W, Wang Z, Han X (2013) Nitrogen deposition weakens plant-microbe interactions in grassland ecosystems. Glob Chang Biol 19(12):3688-3697

Wilke A, Harrison T, Wilkening J, Field D, Glass EM, Kyrpides N, Mavrommatis K, Meyer F (2012) The M5nr: a novel non-redundant database containing protein sequences and annotations from multiple sources and associated tools. BMC Bioinfo 13(1):141

Xu G, Fan X, Miller AJ (2012) Plant nitrogen assimilation and use efficiency. Annu Rev Plant Biol 63:153-182

Zeng J, Liu X, Song L, Lin X, Zhang H, Shen C, Chu H (2016) Nitrogen fertilization directly affects soil bacterial diversity and indirectly affects bacterial community composition. Soil Biol Biochem 92:41-49

Zhang Y, Shen H, He X, Thomas BW, Lupwayi NZ, Hao X, Thomas MC, Shi X (2017) Fertilization shapes bacterial community structure by alteration of soil pH. Front Microbiol 8:1325

Zhu Y-G, Su J-Q, Cao Z, Xue K, Quensen J, Guo G-X, Yang Y-F, Zhou J, Chu H-Y, Tiedje JM (2016) A buried Neolithic paddy soil reveals loss of microbial functional diversity after modern rice cultivation. Sci Bull 61(13):1052-1060

\section{Publisher's Note}

Springer Nature remains neutral with regard to jurisdictional claims in published maps and institutional affiliations.

Ready to submit your research? Choose BMC and benefit from:

- fast, convenient online submission

- thorough peer review by experienced researchers in your field

- rapid publication on acceptance

- support for research data, including large and complex data types

- gold Open Access which fosters wider collaboration and increased citations

- maximum visibility for your research: over $100 \mathrm{M}$ website views per year

At $\mathrm{BMC}$, research is always in progress.

Learn more biomedcentral.com/submissions 